\title{
Antimicrobial, Antioxidant and Cytotoxic Activities of Glochidion multiloculare (Roxb. ex Willd.) Müll. Arg. (Euphorbiaceae)
}

\author{
A.T.M. Zafrul Azam, Abdullah Al Hasan, Md. Gias Uddin, \\ Mohammad Mehedi Masud and Choudhury Mahmood Hasan
}

Phytochemical Research Laboratory, Department of Pharmaceutical Chemistry, Faculty of Pharmacy, University of Dhaka, Dhaka-1000, Bangladesh

\begin{abstract}
The methanol extract (ME) of the powdered bark of Glochidion multiloculare and its six vacuum liquid chromatographic (VLC) fractions $\left(\mathrm{F}_{\mathrm{a}-\mathrm{f}}\right)$ were investigated for antimicrobial, cytotoxic and antioxidant activities. Only fractions $F_{c}$ and $F_{d}$ showed mild antimicrobial activity. Significant free radical (DPPH) scavenging activity was found in $\mathrm{F}_{\mathrm{f}}\left(\mathrm{IC}_{50}\right.$ value $\left.=9.27 \pm 0.117 \mu \mathrm{g} / \mathrm{ml}\right)$. The total phenolic content was measured involving Folin-Ciocalteu reagent and it was the highest in fraction $\mathrm{F}_{\mathrm{e}}\left(187.00 \pm 1.74 \mathrm{mg}\right.$ of GAE/gm of sample). Cytotoxicity (LC $\mathrm{L}_{50}$ ) by brine shrimp lethality bioassay was found to be significant for $F_{b}(0.023 \pm 0.001 \mu \mathrm{g} / \mathrm{ml}), F_{c}(0.3 \pm 0.01 \mu \mathrm{g} / \mathrm{ml})$ and $F_{d}$ $(0.117 \pm 0.0015 \mu \mathrm{g} / \mathrm{ml})$.
\end{abstract}

Keywords: Glochidion, antimicrobial, brine shrimp lethality bioassay, total phenolic content, free radical scavenging.

\section{INTRODUCTION}

Glochidion was regarded as a genus of the family Euphorbiaceae. But molecular phylogenetic studies have shown that Phyllanthus is paraphyletic over Glochidion. A recent revision of the family Phyllanthaceae has subsumed Glochidion into Phyllanthus. ${ }^{1}$ Glochidion multiloculare (Roxb. ex Willd.) Müll. Arg., Phyllanthaceae (synonym: Phyllanthus multilocularis) is an evergreen shrub or small tree which is found in Bhutan, India, Myanmar, Nepal and Bangladesh.

Biological investigations of Phyllanthus species revealed that many members of the genus possess anti-tumor promoting ability, ${ }^{2-4}$ antiviral activity against hepatitis B virus, ${ }^{5,6}$ anti-angiogenic, ${ }^{2}$ lipid lowering activity, ${ }^{7}$ antidiabetic, ${ }^{8-10}$ antiherpetic activity, ${ }^{11,12}$ anti-HIV, ${ }^{13-15}$ antiplasmodial ${ }^{16}$ and other activities. However, no biological studies of $G$. multiloculare have been found in literature to date.

Correspondence to: A.T.M. Zafrul Azam

Tel. +880-1710-880064; Fax: +880-2-8615583;

Email: zafrulazam@du.ac.bd

Dhaka Univ. J. Pharm. Sci. 11(2): 117-120, 2012 (December)
Several secondary metabolites were isolated from different Glochidion species, including tannins, ${ }^{17}$ glycosides, ${ }^{18}$ lignans, ${ }^{19}$ terpenoids. ${ }^{20}$ Previous investigations of Glochidion multiloculare revealed glochidiol, glochilocudiol, glochidone, lupeol, dimedone etc. ${ }^{21,22}$

The present work was an endeavor to screen the methanolic extract (ME) of the barks of $G$. multiloculare and its chromatographic fractions for probable antibacterial, cytotoxic and antioxidant activities and we, herein, report the results of our preliminary studies.

\section{MATERIALS AND METHODS}

Plant material. Glochidion multiloculare (Roxb. ex Willd.) Müll. Arg., (Euphorbiaceae) was collected from Rajendrapur, Gazipur, Bangladesh in the month of August, 2009 and was identified in Bangladesh National Herbarium, Dhaka, Bangladesh. A voucher specimen (DACB Accession No. 34391) of the plant has been deposited in the herbarium.

Production of extracts. The powdered bark (700 g) of G. multiloculare was soaked in methanol (3 L) for 15 days. Part of the residue (10 g) obtained 
from methanol extract was subjected to vacuum liquid chromatography using $n$-hexane, $n$-hexaneEtOAc, EtOAc, EtOAc-MeOH, $\mathrm{MeOH}, \mathrm{MeOH}-\mathrm{H}_{2} \mathrm{O}$ and $\mathrm{H}_{2} \mathrm{O}$ in order of increasing polarities. As a result, 15 fractions (each $100 \mathrm{ml}$ ) were obtained and on the basis of TLC behavior same were combined to yield test samples $F_{a}(1-3), F_{b}(4-6), F_{c}(7-8), F_{d}(9-10), F_{e}$ (11-12) and $\mathrm{F}_{\mathrm{f}}$ (13-15).

In vitro antimicrobial activity. The samples were tested for antimicrobial activity by the disc diffusion method. ${ }^{23}$ The screening was done against 13 strains of bacteria. The results thus obtained were compared with standard antibiotic, kanamycin (30 $\mu \mathrm{g} / \mathrm{disc})$.

Cytotoxicity by brine shrimp lethality bioassay. In brine shrimp lethality bioassay ${ }^{24}$ dimethyl sulfoxide (DMSO) was used as a solvent and negative control while vincristine sulfate (VS) served as the positive control. For cytotoxicity screening, DMSO solutions of the test samples were applied against Artemia salina in a 1-day in vivo assay. For the experiment, $4 \mathrm{mg}$ of each of the test samples was dissolved in DMSO and solutions of varying concentrations $(400,200,100,50,25,12.50$, $6.25,3.125,1.563,0.781 \mu \mathrm{g} / \mathrm{ml}$ ) were obtained by serial dilution technique.

Total phenolics analysis. Total phenolics of the samples were measured by Folin-Ciocalteu reagent. ${ }^{25}$ To $0.5 \mathrm{ml}$ of sample solution $(0.25 \mathrm{mg} / \mathrm{ml})$ in water, $2.5 \mathrm{ml}$ of Folin-Ciocalteu reagent (diluted 10 times with water) and $2.0 \mathrm{ml}$ of sodium carbonate $(7.5 \%$ $\mathrm{w} / \mathrm{v}$ ) solution were added. After 20 minutes of incubation at room temperature the absorbance was measured at $760 \mathrm{~nm}$ using UV-visible spectrophotometer. Total phenolics were quantified by calibration curve obtained from measuring the known concentrations of standard gallic acid (0-100 $\mu \mathrm{g} / \mathrm{ml})$. The phenolic contents of the sample were expressed as mg of GAE (gallic acid equivalent)/gm of the sample.

Free radical scavenging activity. The free radical scavenging activity (antioxidant capacity) of the test samples was assessed by 1,1-diphenyl-2picrylhydrazyl (DPPH). ${ }^{26}$ Here, $2.0 \mathrm{ml}$ of a methanol solution of the sample (test sample/ standard) at different concentration ( $500 \mu \mathrm{g} / \mathrm{ml}$ to $0.977 \mu \mathrm{g} / \mathrm{ml}$ ) were mixed with $3.0 \mathrm{ml}$ of a DPPH methanol solution (20 $\mu \mathrm{g} / \mathrm{ml})$. After $30 \mathrm{~min}$ of reaction at room temperature in dark place the absorbance was measured at $517 \mathrm{~nm}$ by UV spectrophotometer by using methanol as blank. Inhibition of free radical DPPH in percent (I \%) was calculated as follows:

$$
(I \%)=\left(1-A_{\text {sample }} / A_{\text {blank }}\right) \times 100
$$

Where $A_{\text {sample }}$ is the absorbance of the sample and $A_{\text {blank }}$ is the absorbance of the control (containing all reagents except the test material). Sample concentration providing $50 \%$ inhibition $\left(\mathrm{IC}_{50}\right.$ ) was calculated from the graph plotted with inhibition percentage against sample/standard concentration.

Statistical analysis. Three replicates of each sample were used for statistical analysis and the values are reported as mean $\pm S D(n=3)$. Probability (P) value of 0.05 or less $(\mathrm{P}<0.05)$ was considered significant.

\section{RESULTS AND DISCUSSION}

In vitro antimicrobial activity. In vitro antibacterial activity of the test samples were investigated against five gram positive bacteria namely, Bacillus cereus, B. megaterium, B. subtilis, Sarcina lutea, Staphylococcus aureus and eight gram negative bacteria namely, Escherichia coli, Pseudomonas aeruginosa, Salmonella Paratyphi, Salmonella Typhi, Shigella boydii, Sh. dysenteriae, Vibrio mimicus, and $V$. parahaemolyticus. Test samples $F_{c}$ and $F_{d}$ showed weak antimicrobial activity but other samples were found to be inactive. The zone of inhibition of $F_{c}$ and $F_{d}$ were found to be $8-9 \mathrm{~mm}$ and $7-9 \mathrm{~mm}$, respectively, at $400 \mu \mathrm{g} / \mathrm{disc}$ against all test organisms. The zone of inhibition of samples was compared with the zone of inhibition of kanamycin (30 $\mu \mathrm{g} /$ disc) which showed $30-32 \mathrm{~mm}$ of zone of inhibition against all test organisms.

\section{Cytotoxicity by brine shrimp lethality} bioassay. In the cytotoxicity screening the $\mathrm{LC}_{50}$ values obtained from the best-fit line slope were found to be significant (in comparison with VS, $0.423 \mu \mathrm{g} / \mathrm{ml})$ for $F_{b}(0.023 \pm 0.001 \mu \mathrm{g} / \mathrm{ml}), \quad F_{c}$ 
$(0.3 \pm 0.01 \mu \mathrm{g} / \mathrm{ml}), F_{d}(0.117 \pm 0.0015 \mu \mathrm{g} / \mathrm{ml})$ and $F_{\mathrm{e}}$ $(8.17 \pm 0.036 \mu \mathrm{g} / \mathrm{ml})$. The $\mathrm{LC}_{50}$ values for the other samples were found to be somewhat significant (9.04-85.92 $\mu \mathrm{g} / \mathrm{ml})$ in comparison to positive control.

Antioxidant activity. Total phenolic content of G. multiloculare extractives was found to be the highest in $\mathrm{F}_{\mathrm{e}}(187.00 \pm 1.74 \mathrm{mg}$ of $\mathrm{GAE} / \mathrm{gm}$ of sample) and the lowest in $F_{b}(18.82 \pm 0.36 \mathrm{mg}$ of
GAE/gm of sample) (Table 1). In addition, $G$. multiloculare extractives were subjected to free radical scavenging activity using $\mathrm{DPPH}$ by using ascorbic acid (ASA) and tert-butyl-1-hydroxytoluene (BHT) as reference standards (Table 1). Free radical scavenging activity was found to be significant in $F_{f}$ $\left(\mathrm{IC}_{50}\right.$ value is $\left.9.27 \pm 0.117 \mu \mathrm{g} / \mathrm{ml}\right)$.

\section{Table 1. Total phenolic content and free radical scavenging activity of $G$. multiloculare extractives}

\begin{tabular}{ccc}
\hline Sample & $\begin{array}{c}\text { Total phenolic content } \\
(\mathrm{mg} \text { of } \mathrm{GAE} / \mathrm{gm} \text { of sample })\end{array}$ & $\begin{array}{c}\text { Free radical scavenging activity } \\
\left(\mathrm{IC}_{50} \text { in } \mu \mathrm{g} / \mathrm{ml}\right)\end{array}$ \\
\hline BHT & - & $20.45 \pm 0.17$ \\
$\mathrm{ASA}$ & - & $2.9 \pm 0.04$ \\
$\mathrm{ME}$ & $100.87 \pm 1.88$ & $16.46 \pm 0.32$ \\
$\mathrm{~F}_{\mathrm{a}}$ & $19.82 \pm 0.26$ & Value too high i.e. no activity \\
$\mathrm{F}_{\mathrm{b}}$ & $18.82 \pm 0.36$ & Value too high i.e. no activity \\
$\mathrm{F}_{\mathrm{c}}$ & $23.87 \pm 0.35$ & $17.82 \pm 0.106$ \\
$\mathrm{~F}_{\mathrm{d}}$ & $186.45 \pm 2.57$ & $33.92 \pm 0.175$ \\
$\mathrm{~F}_{\mathrm{e}}$ & $187.00 \pm 1.74$ & $23.72 \pm 0.11$ \\
$\mathrm{~F}_{\mathrm{f}}$ & $176.22 \pm 3.6$ & $9.27 \pm 0.117$ \\
\hline
\end{tabular}

The average values of three replicates are presented as mean \pm S.D. (Standard Deviation).

Therefore, it can be concluded that, in the preliminary studies, some of the test samples obtained from the bark of $G$. multiloculare revealed mild antibacterial activity while significant antioxidant activity as well as strong cytotoxicity.

\section{REFERENCES}

1. Hoffmann, P., Kathriarachchi, H. and Wurdack, K.J. 2006. A phylogenetic classification of Phyllanthaceae (Malpighiales; Euphorbiaceae sensu lato). Kew Bull. 61, 37-53.

2. Huang, S.T., Yang, R.C., Lee, P.N., Yang, S.H., Liao, S.K., Chen, T.Y. and Pang, J.H.S. 2006. Anti-tumor and antiangiogenic effects of Phyllanthus urinaria in mice bearing Lewis lung carcinoma. Int. Immunopharmacol. 6, 870-879.

3. Rajeshkumar, N.V., Joy, K.L., Kuttan, G., Ramsewak, R.S., Nair, M.G. and Kuttan, R. 2002. Antitumour and anticarcinogenic activity of Phyllanthus amarus extract. $J$. Ethnopharmacol. 81, 17-22.

4. Tanaka, R., Kinouchi, Y., Wada, S.-ichi and Tokuda, H. 2004. Potential anti-tumor promoting activity of lupane-type triterpenoids from the stem bark of Glochidion zeylanicum and Phyllanthus flexuosus. Planta Med. 70, 1234-1236.

5. Lam, W.Y., Leung, K.T., Law, P.T.W., Lee, S.M.Y., Chan, H.L.Y., Fung, K.P., Ooi, V.E.C. and Waye, M.M.Y. 2006.
Antiviral effect of Phyllanthus nanus ethanolic extract against hepatitis B virus (HBV) by expression microarray analysis. J. Cell Biochem. 97, 795-812.

6. Venkateswaran, P.S., Millman, I. and Blumberg, B.S. 1987. Effects of an extract from Phyllanthus niruri on hepatitis B and woodchuck hepatitis viruses: in vitro and in vivo studies. Proc. Natl. Acad. Sci. USA. 84, 274-278.

7. Khanna, A.K., Rizvi, F. and Chander, R. 2002. Lipid lowering activity of Phyllanthus niruri in hyperlipemic rats. J. Ethnopharmacol. 82, 19-22.

8. Adeneye, A.A., Amole, O.O. and Adeneye, A.K. 2006. Hypoglycemic and hypocholesterolemic activities of the aqueous leaf and seed extract of Phyllanthus amarus in mice. Fitoterapia. 77, 511-514.

9. Raphael, K.R., Sabu, M.C. and Kuttan, R. 2002. Hypoglycemic effect of methanol extract of Phyllanthus amarus Schum \& Thonn on alloxan induced diabetes mellitus in rats and its relation with antioxidant potential. Indian J. Exp. Biol. 40, 905-909.

10. Srividya, N. and Periwal, S. 1995. Diuretic, hypotensive and hypoglycaemic effect of Phyllanthus amarus. Indian J. Exp. Biol. 33, 861-864.

11. Álvarez, Á.L., Del Barrio, G., Kourí, V., Martínez, P.A., Suárez, B. and Parra, F. 2009. In vitro anti-herpetic activity of an aqueous extract from the plant Phyllanthus orbicularis. Phytomedicine 16, 960-966. 
12. Yang, C.-M., Cheng, H.-Y., Lin, T.-C., Chiang, L.-C. and Lin, C.-C. 2007. The in vitro activity of geraniin and 1,3,4,6tetra-O-galloyl- $\beta$-D-glucose isolated from Phyllanthus urinaria against herpes simplex virus type 1 and type 2 infection. J. Ethnopharmacol. 110, 555-558.

13. Notka, F., Meier, G.R. and Wagner, R. 2003. Inhibition of wild-type human immunodeficiency virus and reverse transcriptase inhibitor-resistant variants by Phyllanthus amarus. Antiviral Res. 58, 175-186.

14. Notka, F., Meier, G. and Wagner, R. 2004. Concerted inhibitory activities of Phyllanthus amarus on HIV replication in vitro and ex vivo. Antiviral Res. 64, 93-102.

15. Ogata, T., Higuchi, H., Mochida, S., Matsumoto, H., Kato, A., Endo, T., Kaji, A. and Kaji, H. 1992. HIV-1 reverse transcriptase inhibitor from Phyllanthus niruri. AIDS Res. Hum. Retroviruses 8, 1937-1944.

16. Luyindula, N., Tona, L., Lunkebila, S., Tsakala, M., Mesia, K., Musuamba, C.T., Cimanga, R.K., Apers, S., De Bruyne, T., Pieters, L. and Vlietinck, A.J. 2004. In vitro antiplasmodial activity of callus culture extracts from fresh apical stems of Phyllanthus niruri: Part 1. Pharm. Biol. 42, 512-518.

17. Chen, L.G., Yang, L.L., Yen, K.Y., Hatano, T., Yoshida, T. and Okuda, T. 1995. Tannins of euphorbiaceous plants. XIII: New hydrolyzable tannins having phloroglucinol residue from Glochidion rubrum BLUME. Chem. Pharm. Bull. 43, 2088-2090.

18. Otsuka, H., Kijima, H., Hirata, E., Shinzato, T., Takushi, A., Bando, M. and Takeda, Y. 2003. Glochidionionosides A-D: megastigmane glucosides from leaves of Glochidion zeylanicum (Gaertn.) A. Juss. Chem. Pharm. Bull. 51, 286290.
19. Otsuka, H., Hirata, E., Shinzato, T. and Takeda, Y. 2000. Isolation of lignan glucosides and neolignan sulfate from the leaves of Glochidion zeylanicum (Gaertn) A. Juss. Chem. Pharm. Bull. 48, 1084-1086.

20. Hui, W.-H. and Li, M.-M. 1976. Lupene triterpenoids from Glochidion eriocarpum. Phytochemistry 15, 561-562.

21. Hasan, A.A., Azam, A.T.M.Z., Haque, M.R. and Hasan, C.M. 2012. Triterpenoids and steroids isolated from aerial parts of Glochidion multiloculare. Pak. J. Sci. Ind. Res., 55, 163-168.

22. Talapatra, S.K., Bhattacharya, S., Maiti, B.C. and Talapatra, B. 1973. Structure of glochilocudiol. New triterpenoid from Glochidion multiloculare. Natural occurrence of dimedone. Chemistry \& Industry (London, United Kingdom) 21, 10331034.

23. Bauer, A. W., Kirby, W. M., Sherris, J. C., and Turck, M. 1966. Antibiotic susceptibility testing by a standardized single disc method. Am. J. Clin. Pathol. 45, 493-496.

24. Meyer, B. N., Ferrigni, N. R., Putnam, J. E., Jacobsen, L. B., Nichols, D. E., and McLaughlin, J. L. 1982. Brine shrimp: a convenient general bioassay for active plant constituents. Planta Med. 45, 31-34.

25. Skerget, M., Kotnik, P., Hadolin, M., Hras, A. R., Simonic, M., and Knez, Z. 2005. Phenols, proanthocyanidins, flavones and flavonols in some plant materials and their antioxidant activities. Food Chem. 89, 191-198.

26. Brand-Williams, W., Cuvelier, M. E., and Berset, C. 1995. Use of a free radical method to evaluate antioxidant activity. LWT - Food Sci. Technol. 28, 25-30. 